\title{
MODALIZATION IN THE POLITICAL COLUMN OF TEMPO MAGAZINE
}

\author{
ARTICLE \\ Submitted in Partial Fulfillment of the Requirements for the Degree of \\ Sarjana Sastra
}

By:

MARIA BETTI SINAGA

Registration Number: 2121220007

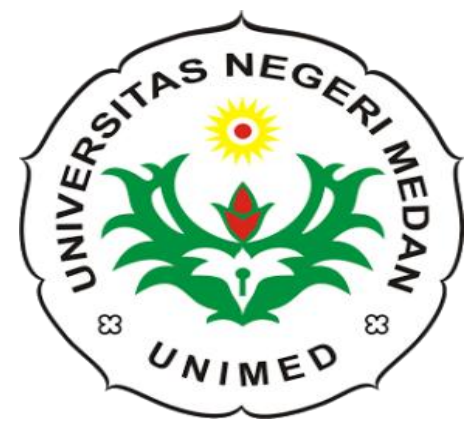

ENGLISH AND LITERATURE DEPARTMENT

FACULTY OF LANGUAGE AND ARTS

STATE UNIVERSITY OF MEDAN

2017 


\section{ARTIKEL MAGAZINE \\ Disusun dan Diajukan oleh: \\ Maria Betti Sinaga \\ NIM. 2121220007}

MODALIZATION IN THE POLITICAL COLUMN OF TEMPO

Telah diverifikasi dan dinyatakan memenuhi syarat

Untuk diunggah pada jurnal online

Medan, Maret 2017

Menyetujui

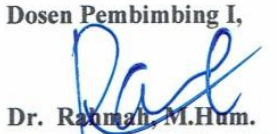

NIP. 196012141987032001
Dosen Pembinkbing II,

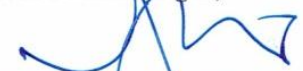

Dr. Anni Holila Palungan, M.Hum NIP. 1970052222001122001

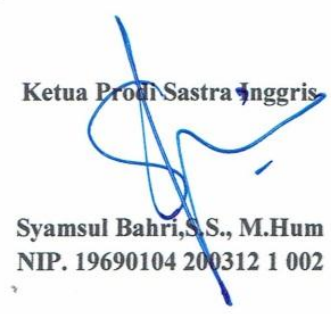




\title{
Modalization in the Political Column of Tempo Magazine
}

\author{
* Maria Betti Sinaga \\ ** Dr. Rahmah, M.Hum. \\ *** Dr. Anni Holila Pulungan
}

\begin{abstract}
Sinaga, Maria Betti. 2016. Modalization in the Political Column of Tempo Magazine. Thesis, English and Literature Department. Faculty of Language and Arts, State University of Medan.
\end{abstract}

The study focuses on analyzing the use of modalization in the Political Column of Tempo Magazine. The objectives were to find out the type of modalization and to describe the use of modalization in the Political Column of Tempo magazine. The data were taken from Political Column of Tempo magazine published in June and July 2017. The source of data was Political Column in Tempo magazine. The data analysis applied descriptive qualitative research. There were 135 clauses which contained Modalization from political columns. There were two type of modalization used in the Political column namely, Probability and Usuality. The dominant type of Modalization used in Political text was Probability 97,7\% then Usuality $2,93 \%$. The probability itself was realized by modal auxiliaries and modal adjunct. The modal auxiliary which expressed the use of probability in the text was should. The value of the modalization itself was realized by medium value. The use of modalization expressed the attitude of the writer toward the proposition. The use of medium value showed the prediction of the writer about what would happen in the future and expressed the stance of the writer for what he said.

Key words: Modalization, Political text, Tempo

\footnotetext{
* Graduate Status

**Lecturer Status
} 


\section{INTRODUCTION}

\section{Background of the Study}

The way human use language is classified into three functionl components; to describe, to exchange, to organize. First language is used to describe or represent the experience about the flow of event wheter is sensing, doing, saying, being, and having. This is also known as ideational function. Second, language is used to enable human to interact with others, to express feeling, judgement, and attitude. This is known as interpersonal function. Third, in delivering the experience has some form organization whereby fit in with or has the cohesion and coherence between the text itself. It is known as textual function. The three function of language called as metafunction.

As explained above one of the function of language is interpersonal function where the language itself used to create communication. the main purpose of communicating is to interact with other; to establish and maintain appropriate social links with them, (Thompson, 1996:38). Interaction inherently involves speaker and listener or reader and writer. interaction also means that exchanging something either given which implies there is something received or else demanded which implies there is somethind given. For example when the speaker asking a question, the speaker demand the listener to give information needed. If not, there is no interaction. The commodity being exchanged can be either information or good and service. 
The interpersonal function focuses with the mood and modality system. mood relates to the speech function whereas modality if relates to the judgement or attitude of the speaker in conveying opinion. It refers to the degree and the responsibility of the speaker toward the proposition. It shows whether the speaker lack of commitment, strong commitment, or low commitment to the validity of his proposition. Therefore, modality means how language user can impose his information.

There are two kinds of modality they are modalization and modulation. Modalization relates to how the information to be true or how frequently it is true whereas modulation relates to how confident the speaker can be eventual success of the exchange. Modality is also has three basic value; High, Medium, and low. high shows the certainty of the speaker and expresses strong opinion. medium and low value shows the uncertainty of the speaker and also expresses weak opinions.

Delivering information is one kind of commodity that is exchanged in interaction. Opinion is one of the kinds of information. it is used to persuade and influence reader of the writer point of view about event that happening in time. In order to persuade, the language used is must be powerful. in delivering opinion the writer can be comment about politics. The opinion itself then is published in the column of the magazine. Opinion column in magazine means to give the chance to the readers to comment the event that happening in time or to draw a conclusion about an issue. 
The validity of the proposition in the opinion can be seen from the modality used by the writer in delivering his opinion. Modality is the truth value of the proposition. it allows the writer to express their interpersonal meaning. It is also expressing the attitude and the commitment of the writer. modality is a sign that the writer is presinting a personal view rather than objective facts. Using modality express the stance of the writer toward his proposition.

There were previous study about modality firstly, Dong (2013) conducted a research about interpersonal Metaphor in legal Discourse: Modality in Cross-examination. He found that the modality used by the lawyer is different with the witness. Laywer use high and medium modality such as never, would, will, and usually. Witnes uses low modality such as I think, I guess, I am not sure.

The other research is modality in literary from Arabic into English and French. In this research found that the modality in English more functional and it enhances more meanings. In English contains all expressing modalities, whereas the French contains expressing modalities except probabiliy and willingness.

From the explanation above, Modalization is important to learn, especially in the opinion column to know how the writer express attitude through the proposition. Analyzing modalization in text also make the reader understand what the purpose of the writer in conveying opinion. Modalization also can be used to know how responsible the writer toward the opinion, how he draw a conclusion about event that happening in time. 


\section{Review of Literature}

\section{Interpersonal Function}

The interpersonal function is an interpretation of language in its function as an exchange, which is doing function of language; it is concerned with language as action. The clause is organized as an interactive event that involves speaker, or writer, and audience (listener or reader). Clause of the interpersonal meaning function as clauses of exchange, which represent speech role relationships. Whenever two people use language to interact, one of the things they do with it is establishing a relationship between them.

The interpersonal relationship of interactant is realized through mood or modality. The modality is construe the region of uncertainty that lies between 'yes' and 'no'.

\section{Modality}

Halliday and Matthiessen (2004:618) define modality as the area of meaning that lies between yes and no. Modality construe the region of uncertainty that lies between 'yes' and 'no'.

Modality is divided into three according to language used has different function in communicative; type and value. There are two types of modality; modalization and modulation. Halliday and Matthiessen (2004:147) states that modalization is the speaker judgement to proposition (information commodity: statement and question). Modulation is a subjective consideration to proposal 
(Haliday and Matthiessen, 2004:147). Modulation is divided into obligation which is 'is wanted' to carry out a command addressed to the second person and inclination, namely 'want to' to do an offer, typically carried out by the first person.

To analyze the degree and scales of modality Halliday and Matthiessen (2004:620) determined three basic values of modality attached to modal judgement they are; High, Median, Low. Value means as the level or the degree of the modality. High modal verb expreses strong opinions and confidence of the speaker about the fact they known. On the contrary, medium and low modal forms stand for weaker opinions. Modality can be realized by various kinds of linguistic units, such as modal operator (can/could, may/might, should/ought to, will/would, shall, must), modal adjunct (probably, possibly, certainly, perhaps, maybe).

\section{Language of Media}

As a tool of communication, language is one of the essentials in mass media. The language usually makes the communication persuasive and effective one. Media language aims at attracting the attention of the readers. The language in media is also vague means there are possible states of things concerning which it is intrinsically uncertain whether, had they been contemplated by the speaker, he would have regarded them as excluded allowed by the proposition. In other word, a speaker may produce utterances without deciding whether certain facts are excluded or allowed by him. The language is vague if the meaning of the word arises from intrinsic uncertainty. Vague language refers to "any purposive choice 
of language designed to make the degree of accuracy, certainty. The vaguness applied when accurate description or statement are impossible due to the nature of the products or service and special needs are to be imaginative.

\section{Language Features in Politics}

The language in politics is used to argue or debate, persuade, critique, and inform public policy. The language in politics is usually used by the goverment in order to persuade other. The validity of politics language is subjective and relative. The validity of the politics is more relative then law. In the politics is hard to decide it is constantly positive or negative. In political text, ideas and ideology need to convey through language. In politic everything can change, it is according to the situation. People can't predict what will happen next because there are many factors that can change the situation. In politics, people usually hide themselves behind these skills so as not to attach themselves to any kind of commitment.

\section{Tempo magazine}

Tempo is an Indonesia weekly magazine that covers news and politics. It was founded by Goenawan Mohamad and Yusril Djalinus. The style of journalism is different from other Indonesian daily newspaper. Tempo provides news in the style of what they call the story behind the story. So, what is served to the readers is not only current events, but also the story following and behind the news. 


\section{RESEARCH METHODOLOGY AND FINDINGS}

\section{Methodology}

This study was conducted by using descriptive qualitative method because the intention of this study was to describe the analysis of Modalization in the political column of Tempo and the realization of the modalization in the text.

Kothari (2004:4) figures out that qualitative research was concern with qualitative phenomenon that is phenomena relating to or involving quality or kinds. The qualitative research focuses on the total picture rather than breaking it down into variables.

\section{Techniques of Analyzing the Data}

There are three components of analyzing data they are data reduction, data display, and conclusion (Miles and Huberman, 1992). The steps are described as following:

1. Data reduction is the process of selecting and identifying the clauses contain of modalization. Then the data categorized and labeled the clause based on the types of modalization and value.

2. Data display is the process where the data will organized. The researcher displayed the data into table. Then the implications of the using modalization in the political column is described.

3. After reducing and displaying the data, the next step was drawing conclusion. It considers to analyzed the meaning and the implication of the data. 


\section{Findings}

Based on the data analysis, the findings of this study are formulated as follows:

Based on the data analysis, the findings of this study were formulated as follows:

1. In writing the opinion, the use of two sub modalization - probability and usuality- were found, but not all the writers used the two of type of modalization, there were only three writers use the two type of modalization: text $4,10,11$. The other writers used the probability only.

2. Medium value was the most dominant in the political texts. This was realized by the use of modal such as will, should, could, can, uncertainty. It was used to convey the attitude of the writer toward the events.

3. The use of probability as the dominant type of modalization with medium value expressed that the writer of the opinion column talked about the future event. The writer gave the prediction about the future event. Moreover, the political event was unpredictable to be happened. The modalization also aimed to avoid the offence of the reader because the reader was have the chance to argue about the opinion.

\section{CONCLUSION AND SUGGESTION}

\section{Conclusion}

Having analyzed the data, conclusion were drawn as follows:

1. The political text of opinion column of Tempo used the two types of modalization, they were probability and usuality. Even the two types were 
not used by all the opinion's writers in writing the appropriate modalization made the opinion was accepted by the reader.

2. In realizing the use of modalization in the opinion column of tempo the writer used probability with medium value. It was realized by modal auxiliary "Should". The use of modalization by the writer expressed the attitude of the writer toward the proposition. The use of medium value showed the prediction of the writer about what would happen in the future. It also showed how the opinion likely or unlikely to be true.

\section{Suggestions}

In accordance with the conclusion the writer gives some suggestions as seen in the following:

1. The students of English Department and the linguists were suggested to have a good comprehension in modality's theory then do further research. Therefore, they would be able to comprehend the text form the perspective of functional grammar and more understand the text clearly.

2. The columnist and other researchers were suggested to apply the appropriate modality in his text. The appropriate modality made the reader accept the idea then their ideas sound more effectively and intelligibly.

\section{REFERENCES}

Asdinlou and Valipour. 2014. An Investigation of Metaphorical Modality in Barack Obama's Speeches from Systemic Functional Perspective. Iran. International Journal of Basic and Applied Sciences. 3(1), 28-33.

Christians and Wilkins. 2009. Mass Media Ethics. New York. Routledge. 
Dong,J. 2013 . "Interpersonal Metaphor in Legal Discourse: Modality in CrossExaminations". Journal of Language Teaching and Research. 4(6), 13111321.

Eggins, S. (1994). An Introduction to Systemic Functional Linguistic.London: Printer Publishers.

Feng \& Liu. 2010. "Analysis of Interpersonal Meaning in Public Speeches- A case study of Obama's Speech”. Journal of Language Teaching and Research.1(6), 825-829.

Gerot. W. 1994. Making Sense of Functional Grammar. Sydney: Gerld Stabler.

Guerra, Hernandez. 2013. Textual, Intertextual and Rhetorical Features in Political Discourse: The Case of President Obama in Europe. Revista de Linguistic Lengua Aplicadas. Vol 8, 59-65. Accessed on January $19^{\text {th }}$ .2014 .

Halliday and Matthiessen. 2004. An Introduction to Functional Grammar. New York: Arnold.

Keeble, R. 2006. The Newspaper Handbook. New York: Taylor and Francis group.

Kothari. 2004. Research Methodology Methods and Techniques. Delhi: New age International.

Moindjie. 2015. "The Function of Modality in Translation". International Journal of Comparative Literature \& Translation Studies. 3(2), 11-24.

Mao. et. al.2014. "Corpus Functional Stylistic Analysis of Modal Verbs in Major Barbara and Its Chinese Versions". Theory and Practice in Language Studies. 4(1), 70-78.

Matthiessen and Painter. 1997.Working with Functional Grammar.New York: Arnold.

Miles and Huberman. 1992. Qualitative Data Analisis. Jakarta: UI press.

Nur, S. 2015. “Analysis of Interpersonal Metafunction in Public Speeches: A case study of Nelson Mandela's Presidential Inauguration Speech".The International Journal of Social Science. 30(1), 53-63.

Palmer, F, R. 1986. Mood and Modality. Cambridge: Cambridge University Press.

Saragih. 2014. Discourse Analysis: A study on Discourse Based on Systemic Functional Linguist Theory: Medan: Unimed

Sinar, S. T. 2002. Linguistic-Oriented Discourse Analysis. Deezed Consult. Singapore. 
Thompson, G. 1996. Introducing Functional Grammar. London: Edward Arnold.

$\mathrm{Xu}$, J. 2009. "Interpreting Metaphor ofModality in Advertising English". China Journal of Linguistics. 2(4), 117-122.

Yuyun, I. 2010. "A study of Arguments in Senior High School Debate". Jurnal Penelitian. 14(1), 129-139.

Zheng, Tongtao. 2000. Characteristics of Australian Political Language Rhetoric: Tactics of Gaining Public Support and Shirking responsibility. November, issue 4: 1-3. Accesed on January $10^{\text {th }}, 2014$. 